\title{
The Behavioral Intention of Tourists toward Local Foods: An Applied Research on the Local Foods Served in Egyptian Siwa Oasis
}

\author{
Mohamed S. Ghanem \\ Hotel Studies Department, Higher Institute for Tourism, Hotels and Computer Science, Alexandria, Egypt \\ Email: M_ghanem_@hotmail.com
}

How to cite this paper: Ghanem, M.S. (2019) The Behavioral Intention of Tourists toward Local Foods: An Applied Research on the Local Foods Served in Egyptian Siwa Oasis. Journal of Service Science and Management, 12, 714-741.

https://doi.org/10.4236/jssm.2019.126049

Received: July 9, 2019

Accepted: September 20, 2019

Published: September 23, 2019

Copyright (c) 2019 by author(s) and Scientific Research Publishing Inc. This work is licensed under the Creative Commons Attribution International License (CC BY 4.0).

http://creativecommons.org/licenses/by/4.0/

\begin{abstract}
Local food linked to every tourist destination in Egypt represents a cultural image of this destination and reflects many of its heritage dimensions. The aim of this study is to explore the impact of tourists' satisfaction of local food experiences and their behavioral intention related to Siwa oasis' local foods as an approach to provide an integrated framework of international promotional plan of Siwa local food. A field survey questionnaire was developed and distributed to 62 tourists who are interested in Siwa Oasis. While the results showed no impact of good memorable local food experience in hosting destination on respondents' behavior intentions to share their experiences to motivate others to try local food, other results showed statistically significant impact of such good memorable on respondents' behavior intentions to use the same food items and cooking styles in their homes, to search the same food items in their home countries, to dine in restaurants that serve these items and to return again to the destination to retry the same local food. The research verifies the major opportunities of Siwa oasis local cuisine. These opportunities are analyzed carefully to provide an integrated framework of international promotional plan of Siwa local food.
\end{abstract}

\section{Keywords}

Food Heritage, Local Food, Tourists' Behavioral Intention and Siwa Oasis Destination

\section{Introduction}

Traditional food and cuisine are represented as an important component in tourism. They are combined to be a major factor in attracting tourists, especially in case of rural and resorted destinations. Because food represents as entertain- 
ment and cultural activities, local food experience adds value to the overall tourism experience of the travelers, makes the tourism journey more unique [1], helps in the differentiation of tourist destinations and leads to the emergence of "food tourism" as an attractive modern tourist style that is popular among the new generation of tourists [2].

Gastronomy can be considered as a key of understanding other cultures [3]. Local food is a fundamental component of the tourism experience of travelers. As many tourists take the decision to visit one destination motivated by their desire to try the local people lifestyle, experiencing local food is essential. Among 20 studied factors that direct the decision of traveling among tourists, the served food and drinks ranked at the 4th. By calculating the correlation coefficient between overall tourist's satisfaction and local food offered, results showed a strong positive significant relationship. Therefore, the study recommended that food should be considered as a good predictor of tourist's satisfaction [4].

Although food is an essential part of the classic tourism product, as it represents almost one-third of the expenditure of tourists, the uniqueness of the offered food product in many destinations has led to the emergence of a new growing international tourist pattern that called "food tourism", where the food product provided at the tourist destination is the main attraction of the tourist trip or at least is one of the main reasons why people travel to specific tourist destinations [5].

The term "food tourism" arises to mind when food is a primary or secondary motivator to travel [6]. It belongs a new tourism type that called "culinary tourism", "gastronomy tourism" [7] or "food tourism" [8] and expressed "tourists who travel to a specific destination to experience specific foods that reflects the authenticity of the destinations heritage and culture" [9]. To determine the concept of "food tourism", it is important to distinguish between the behaviors of tourists who eat local foods as a part of their trip experience and others who come to destination only to experience their local food. Therefore, "food tourism" which called "culinary tourism" may be defined as "visiting destinations for the purpose of gaining gastronomic experiences and enjoying unique local food and beverage" [10]. Thus, not all visits to restaurants in the local community can be categorized as a food tourism case. It is about interesting in culinary, gastronomy or local cuisine when choosing the tourist destination.

As it relates to any travelling that motivated by interests in tasting specific food items, using food ingredients, learning unique cooking methods and styles, purchasing unique food products, attending cooking training courses or food and beverage festivals, watching cooking shows and experiencing food production techniques, food tourism is defined as "traveling to certain tourist destinations offering a unique food product to test unique dishes as a part of a tourist experience that aims to experience the cultural heritage of this tourist destination" [11]. It is "the travelling to taste and experience food items of a specific region" [12]. 
Many literature attributed the steady growth of food tourism in our present time to the lack of time for people to cook their own food, so the inclusion of interest in food as a part of the tourism experience is important because of the entertaining dimension of watching the cooking as a process that reflects the characteristics of the tourist destination as part of the overall tourist's comprehensive experience in the destination, where lives the same lifestyle of citizens of the host community and eat their food [13].

Despite the globally growth of food tourism, some believe that food tourism will witness an unprecedented growth in the near future as a major component of the popular culture of the host communities. This will add an unique competitive advantage that differentiates the tourist destinations with distinctive cultural and heritage patterns, which is due to the constant and diligent search by tourists interested in heritage for everything that is unique and distinctive [14]. Therefore, investigating tourists' intentions and perception toward local cuisine will provide a behavioral framework that leads to more exploitation of local cuisine as a vital tourism attraction.

For no logic reasons, food tourism has been neglected for many years in hospitality literature. While gastronomy is represented as an important factor influencing overall tourism experience, studies that addressed the phenomenon of tourists' gastronomy experiences are limited. The main reason behind such ignorance may be back to the traditional looking at the food as a secondary factor of tourism activity rather than a major tourism attraction in itself [15]. A review of previous literatures indicates that most studies are about investigating the relations between tourism and different destinations' cultural aspects rather than local foods and cuisine [16] [17] [18]. Furthermore, there is a shortage in researches that investigated the role of local cuisine as a marketing tool of destinations and its direct influence on the development of destinations [19].

Moreover, the studies conducted to examine customer behavior towards the local food usually addressed only one single factor as an influential. This factor may be tourist experience toward food [20] [21], tourist motivators to consume local food [22], tourist perceptions of local cuisine experiences or tourist satisfaction [23] [24]. Thus, there is no study that focused on the majority of these combined factors.

There is a relative scarcity of empirical researches that examined local foods' dining experience and its impacts on tourists' behaviors [25]. The majority of studies that had been done to explore tourist behavior is often neglected the influences of local cuisine and foods. Therefore, there is a huge gap in field of local food tourism research literature, especially in regards to consumer behavior [26]. In addition, a review of literatures had been showed limited empirical studies that investigated the behaviors among tourists related to the consumption of local foods [27].

Furthermore, the majority of studies that examined tourist behavior towards the local food are done in or on Asian destinations [28], especially in or on Chi- 
na [29] [30], Thailand [31] [32], Hong Kong China [33], Taiwan China [34] [35], India [36], Singapore [37], Malaysia [38] [39] and Indonesia [40]. Thus there are limited studies in or on Africa [41] [42] and no studies in or on Arab and Egyptian tourist destinations.

This previous review emphasizes on theoretical benefit of this study that categorize the potential tourists' behaviors toward food tourism regarding Siwa. Such categorization could be assist in producing a general framework for behaviors related to local food in other similar destinations. The value of this research paper is explored by its contribution on presenting a guide of tourists' behaviors toward local food belongs Siwa oasis as a developed tourist destination. The research also focuses on defining potential tourists behaviors regarding Siwa local food. Achieving this aim could be relayed on in the process of marketing Siwa as a tourist destination. It helps various stakeholders involved in Siwa's tourism industry (e.g. governmental agencies, hospitality and tourism establishments and other Local and foreign business operators) making various strategic plans related to tourism development in the destination.

This research aims to: explore the impact of guest's satisfaction about local food experiences and their behavioral intention toward Siwa oasis' local Foods, identify the extent of acceptance to experience Siwa oasis local food among tourists, identify the extent of possibility of depending on local food of Siwa as a marketing tool to attract visitors and tourists, verify the opportunities of Siwa oasis local cuisine in supporting the tourism demand for the destination and provide a framework of international promotional plan of Siwa local food. Thus, the research problem could be illustrated in the following questions: what are the impacts of guest's satisfaction about local food experiences on their behavioral intention toward Siwa oasis' local Foods? What is the extent of tourists' acceptance to experience Siwa oasis local food? In what extent local cuisine could contribute in tourism development in Siwa oasis? Are there any real valuable opportunities for marketing Siwa depending on its' local food? If any, what are these opportunities and how to exploit?

\section{Literature Review}

\subsection{Food Tourism Classification}

According to their interactions with food, tourists can be classified into the followings [43]:

- Existential Gastronomy Tourists: They believe that their gastronomy skills can be improved through local food and beverage experiencing. Therefore, eating local food means acquisition in-depth knowledge about the culture and heritage of the destination. Thus, this type of tourists seeks to eat only in places where local residents eat and appreciate only the local food that is follow traditions in preparation.

- The Experimental Gastronomy Tourists: They search for fashionable and trendy foods that related to their lifestyles. They dine in restaurants and cafes 
that satisfy their social needs related to prestige.

- The Recreational Gastronomy Tourists: They don't prefer local food. They tend to dine in modern complex restaurants.

- The Diversionary Gastronomy Tourists: They seek quantity and easy accessible food. Therefore, they prefer to dine in international chain restaurants with familiar menu items.

In the same context, tourists can be classified into [44]:

- Gourmet Tourists: A group of tourists who love food and drink. They prefer luxury restaurants and high-quality drinks. They don't looking for cheap food.

- Gastronomic/Culinary tourists: Includes travelers who follow unique food culture experiences and travel to attend food, drink and cooking festivals.

- Cuisine tourists: This group is interested in certain foods related to a particular region, country or destination.

In regards to food tourism and for more accuracy, there are four distinguished types' food tourists [45]:

- Recreational Food Tourists: They seek the pleasure through dining out and feel happy when trying unfamiliar items of foods during their trip.

- Diversionary Food Tourists: They seek food items that differ from that usual in their everyday life.

- Experiential Food Tourists: They seek innovative food types and enjoy trying new ingredients, unique eating styles and novel preparing methods.

- Existential Food Tourists: They consider experiencing food as a learning way that develops their knowledge about the local destination's culture.

\subsection{Local Food Experiences}

There are three elements that lead to the success of tourist's food experience which are "locality", "authenticity" and "novelty". Thus, these elements are the key factors in distinction between the real local foods and other food items presented to the tourist during the trip. Those who seeking for foods with these three elements are called "foodies" [46].

The term "authenticity" is associated with terms as "real", "origin" and "trustworthy" [47]. Tourists, in general, searching for authentic experiences during their trip to feel different life and gain amazing memories [48]. Thus, evaluating the overall trip experience depends on the extent of authenticity of all component of such experience [49] [50].

Local food can be invested to be an attractive tool that adds value to the tourist destination. In our sophisticated life, tourists often travel to escape the shortage of authenticity in modern life. Thus, discovering more authentic destinations with unique experiences is the major factor influencing tourism phenomenon in recent as local food experiences supports authenticity of the trip. Thus, local food can support the integrated tourism experiences in many ways [51]:

- Linking Tourism to Culture: Local food is represented as a gate to destina- 
tion's culture that supplies both tourists and locals with an opportunity to share cultural experience. Thus, food conveys local customs and traditions.

- Adding Value to the Meal Experience: Meals and dining are in a central in the integrated tourist experience. Thus, local food adds value to the overall tourists' experience by creating meaningful and memorable experiences.

- Serving Distinctive Foods: Local foods are considered to be distinctive elements that support branding the image of destination that helps creating a strategic competitive advantage in the international marketplace.

- Sustaining Local Culture: Local food can develop local culture by providing the necessary capital for sustaining culture.

\subsection{Market Segmentation, Destination Branding and Economic Aspects Related to Local Food Tourism}

Profiling of food tourists in one destination couldn't be typically copied to another. Tourists' market can be classified according to their interest in food provided in the host community into five main groups [52]:

- Food Tourists: Those who traveling mainly for testing and experiencing unique local foods and drinks. Those are about $3 \%$ of international travelers.

- Interested Purchasers: Those who believe that local food and drinks contribute to the satisfaction of their tourist experience. Thus, they seeking for local food when travelling.

- Un-Reached: Those who believe that local food and drink may contribute to the satisfaction of their tourist holiday. Thus, they may try local food if the opportunity arises.

- Un-Engaged: Those who believe that local food mayn't add any value to their tourist holiday, but they aren't refuse to try local foods.

- Laggards: Those who avoid trying local food when travelling.

Food is interlinked with dining habits and social practices of nations and integrated with their traditions and history [53]. Therefore, national food presents a comprehensive view of any destination [54]. The successful globalization of national food should begin with the successful presentation of such food in the local destination itself [55]. The development of mass tourism due to the globalization provides a valuable opportunity for all local products, including local foods, to be known and integrated in the unique cultural history. Depending on this approach, local foods can be copied and globalised to be used for marketing purposes in branding destinations [56] [57]. Generally, there are two results of food experience among tourists, which are:

- Food Image Exposure: Local foods are a major factor in creating the overall tourism experiences as they reflect the destination image and its intangible cultural heritage [58]. Food is deeply expressed the regions heritage and show the destinations distinctiveness compared with other destinations [59]. Integrating food with other local features (i.e. in case of Japanese and Chinese cuisines) is considered as an effective way in developing new gastronomical 
destination brand. Strong exposure to ethnic food in modern communities helps in globalizing such food and support nations to franchise their cuisine in the world that increasing people willingness to travel to its country of origin [60]. From this point of view, local foods are represented as a strong competitive criterion that could be used to enhance the destination image in the way that motivates tourist's revisit intention [61].

- Information Sources and Sharing: Word-of-Mouth (WOM) has been represented as a key aspect in travelling decision making. Therefore, tourist who discovers new tourist's products and destinations acts as an opinion leader through sharing his experiences to other relatives. Food products that reflect destinations' heritage are like other tourist's products affected by WOM and help the formation of travelling decision to any destinations. This can be clearly notices as in cases of Turkey, Hong Kong China, Japan, South Korea, Singapore, Taiwan China and Thailand where WOM regarding their local food contributes effectively in marketing them as unique tourist destinations [62].

There are strong developmental impacts of food tourism on the local economy of the host destination. Unlike other tourism types, food tourism occurs at any time of the year and during any weather condition. It isn't suffered from seasonality that influences most tourism types. It is a high yield tourism type that provides any host community with the following economic advantages [63]:

- Help achieving the diversification of resources in rural economies that has few options of development and create more jobs for residents.

- Attract tourists with high expenditure ratios that help strengthening other elements of the local economy and give an extension to the tourist season.

- Help sustaining the cultural heritage of the community and the local environment.

- Generally, it needs no new investment.

- Push other economic sectors and create structural inter-linkages with other agriculture, construction, industry and service sectors.

\subsection{Local Food and Culture Heritage}

Consuming local food not only increases tourists' knowledge about the local cuisine, but also motivates them to involve in the whole destination's local culture [64]. Thus, local food can be promoted as an icon that reflects the common cultural and heritage of the destination. It can provide the destination with a brand that works stronger than the national dress. The uniqueness of local food nowadays plays a major role in tourist destination selection. Local food heritage depends on combining the local lifestyle, culture and tradition into unique appealing memorable experiences [65]. It's about the taste of experience not the taste of food.

While some literatures suggested that destinations' cultural similarity moti- 
vates people to visit them because of similar background, language or religion [66], many other literatures confirmed that the cultural contrast leads to more tourists' interest in destinations [67] as the tourism activity itself depends on the philosophy of diversification and differentiation.

There are reasons why culinary tourism is represented as an important aspect of local destination's cultural heritage. These reasons are [68]:

- All of foreign tourists tend to dine out when traveling.

- Dining out represented as one of the most three popular travelers' activities.

- Culinary tourists are tending to participate in the majority of outdoor recreational activities.

- Interest in culinary tourism expands to all age groups.

- Food attractions can be offered all year round regardless of seasonality.

- Local cuisine can be the major or at least the secondary factor in motivating tourist to choose the destination.

Local food strongly contributes into the integrated satisfaction of tourist during the trip [69]. It has emerged to offer a complete and perfect sensory experience to tourists. It is also represented as an important reflector of all social, environmental and cultural image of the local destination. Thus, to understand any nation's style of life, it is necessary to understand their food culture [70].

While a meal is considered as an event in itself, many other events like festivals, exhibitions and celebrations can't be completed without offering food [71]. Such events can be planned and developed to support local food experiences. Culinary festivals, slow food salons, food fashion exhibition and online food platforms are examples of how special events can contribute in promoting local foods [72]. Such events act as innovative promotional tools that provide real opportunities to promote local foods to the world and give the chance to knowledge and experience exchange.

\subsection{Factors Affecting Local Food Tourism}

Designing better local food products need better understanding of various factors affecting tourists' behavior toward such type of products [73]. Generally, there are three main factors that influence local food consumption among tourists in the host destinations:

\subsubsection{Demographic Factors}

No one can deny the role of demographic factors in directing people's selection of food product. Factors like age, gender, marital status [74], education level and religious beliefs, for example, have a vital effect on food preference and consumption [75].

Depending on their origin, tourists have different approaches toward culinary experience. However, tourists from Eastern cultures tend to avoid dining in restaurants that serving local foods, others from Western cultures are more tending 
to experience novel foods that are unfamiliar to them [76]. In relation to income and education level, tourists with higher income and education levels are tending to try local gastronomy in touristic destinations because they don't consume food only to satisfy their physical needs, but also to discover the destination's local culture through its local dishes [77]. In reference to age impact, tourists with lower ages are tending to discover and try more than higher age categories. Therefore, they are tending to dine in restaurants that served local food [78].

Tourist gender is important in relation to local food preference, especially in case of meat items and low-calorie food [79]. Males are generally more interested in local food consumption than females as consumption of local foods among females influencing by their weight concerns and low-calorie preferences [80]. Females also are more involved in food safety when compared to males who are focused on taste of local food [81]. With indication to marital status, single females are interested in trying and recommending their local food experiences than married females [82].

\subsubsection{Motivational Factors}

There are many motivational factors that impact tourists' gastronomic behavior and influence the integrated tourists' satisfaction levels [83]. There are some motivational factors like exciting experience, escaping from routine, discovering new things and authentic experience that directing the gastronomic consumption during touristic trip. Tourism gastronomic motivations can be classified into two main categories [84]:

- Symbolic: It refers to learning about local culture, exciting experience, authenticity and prestige.

- Compulsory: It refers to physical needs and health concerns.

According to this classification, experiencing local gastronomy is represented as a symbolic dimension. Depending on such motivational factors, tourists can be categorized according to food-related behaviors into [85]:

- Experiencers: Those who consider food as an essential criterion in destination selection.

- Enjoyers: Those who have positive attitudes towards local food.

- Survivors: Those who consume local food to cover their physiological needs. In line with that, most tourists, who travelling to unique destinations with special heritage, prefer to eat at authentic places rather than in international restaurants [86].

\subsubsection{Psychological Factors}

Overlapping with many motivational factors, there are many psychological factors that influence local food consumption during trips. These factors are about the personality of the tourist himself, the previous exposure to the same experience, the seeking for more variety and the desire to escape from routine lifestyle [87]. 
In relation to previous exposure, many tourists prefer foods they eat before in the same destination. While many tourists when travelling to Asia prefer to stay in modern hotel chains to avoid local strange foods, others who are in continuous search for novelty choose novel local foods [88]. To conclude the situation, there are two psychological dimensions that control local food consumption among tourists:

- Food Neophobia: Dislike tasting novel foods [89].

- Food Neophilia: Curiosity and willingness to taste novel food. It is described to be a push factor that motivates many tourists to try local food and encourage food tourism phenomenon [90].

\subsection{The Impact of Local Food on Tourist's Behavioral Intention}

Generally, the behavioral intention of an individual refers to the tendency of him to exhibit his behavior. Thus, it is basic for any human action to be occurred as it reflects the individual mental status before adopting behavior. Satisfaction of local food experience during their trip motivates tourists to take one or more of the following behaviors:

- Using the same food items and cooking styles in their homes [91], searching the same food items in their home countries and dining in restaurants that serve these items [92].

- Returning again to the destination motivated by their desire to retry the same local food [93] [94].

- Sharing their food experiences toward local food that motivate others to interest in the culture of the destination [95] [96].

- Recommended the destination itself to other relevant [97] [98].

\subsection{The Future of Local Food Tourism}

Recently, there are increasing numbers of tourists who traveled for enjoying and exploring local featured cuisine and food to experience memorable delicacies. Because of its impact on the overall destination image, quality cuisine is arising as an important relevant that affect the destination choosing process [99]. In 2017, the UNWTO reported that gastronomy tourism represented more than $30 \%$ of total revenue of gastronomy in tourism destinations. This revenue margin would expect to grow in the near future as gastronomy would be a distinctive element of destination [100]. At any tourism destination, food products nowadays became an essential attraction factor that helps the process of destination profiling [101].

There are increasing numbers of tourists that targeting not only to sate their appetite but also to enjoy food experience [102]. Gastronomic tourists consider local cuisine as a socializing means that enables them to exchange experiences within the touristic destination. They try to discover the destinations through their food. Thus, they tend to spend higher amount of money to gain such experience in comparison with other styles of tourists [103]. 


\section{Research Hypotheses and Variables}

Depending on the previous theoretical basis, the research paper aims to test the following hypotheses:

- $\mathrm{H}_{1}$ : Good memorable local food experience in hosting destination impacts positively on tourist's using of the same food items and cooking styles in their homes.

- $\mathrm{H}_{2}$ : Good memorable local food experience in hosting destination impacts positively on tourist's searching the same food items in their home countries.

- $\mathrm{H}_{3}$ : Good memorable local food experience in hosting destination impacts positively on tourist's dining in restaurants that serve these items.

- $\mathrm{H}_{4}$ : Good memorable local food experience in hosting destination impacts positively on tourist's returning again to the destination to retry the same local food.

- $\mathrm{H}_{5}$ : Good memorable local food experience in hosting destination impacts positively on tourist's sharing their experiences to motivate others to try such local food.

According to these hypotheses, dependent and independent variables of the research can be illustrated by the model shown in Figure 1 .

\section{Research Methodology}

Depending on descriptive analytical method, the research was accomplished through interviewing of 62 foreign tourists in Siwa oasis. For the research purposes, a special questionnaire was developed to concentrated on investigating the general interest of these tourists' in local food during their travelling, their intention to try Siwa local food and their behavioral intention toward Siwa local food experience. The collected data were analyzed by using PASW Statistics version 18. The reliability of questionnaire was tested by calculating Cronbach's Alpha value (0.967). Statistical techniques of descriptive statistics are used. As the research aims to investigate the impact of tourists' satisfaction of local food experiences on their behavioral intention related to Siwa oasis' local foods, One Linear Simple Regression Analysis was used.

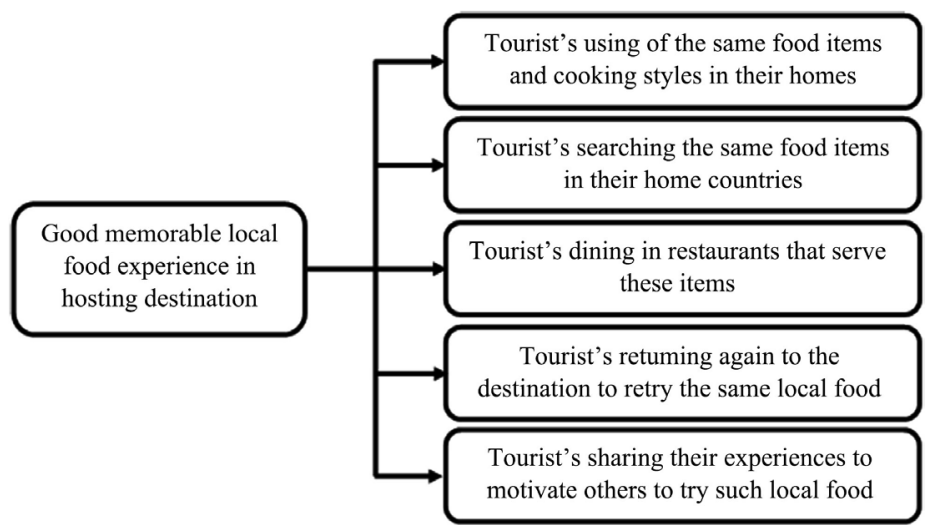

Figure 1. Dependent and independent variables of the research. Source: prepared by author. 


\section{Research Results}

\subsection{Data Presentation and Description}

\subsubsection{Research Sample Characteristics}

As shown in Table 1, 45.2\% of respondents were 60 years and more, the majority of them are males $(77.4 \%)$ and the highest percentage of them $(87.1 \%)$ is highly educated. In the same context, $59.7 \%$ of respondents are with income level that more than $6000 \$, 30.6 \%$ of them are in a relation and the majority of them $(83.9 \%)$ are belongs to Western cultures.

\subsubsection{Attitude of Research Sample toward Siwa Local Cuisine}

Depending on data illustrated in Table 2, more than half of the respondents (51.6\%) are visiting Siwa for the first time and $50 \%$ of them have previously eaten some food items that belongs Siwa's cuisine. About half of research respondents (51.6\%) are expected that trying Siwa local food is a memorable food experience. According to the major reasons that might encourage the respondent

Table 1. Research sample characteristics.

\begin{tabular}{|c|c|c|c|c|c|}
\hline Characteristics & Choices & $\mathbf{F}$ & $\%$ & Mean & $\begin{array}{c}\text { Std. } \\
\text { Deviation }\end{array}$ \\
\hline \multirow{5}{*}{ Age Group } & Under 20 Years & 2 & 3.2 & \multirow{5}{*}{3.7258} & \multirow{5}{*}{1.33268} \\
\hline & 20 to $<35$ Years & 14 & 22.6 & & \\
\hline & 35 to $<45$ Years & 11 & 17.7 & & \\
\hline & 45 to $<60$ Years & 7 & 11.3 & & \\
\hline & 60 Years and more & 28 & 45.2 & & \\
\hline \multirow{2}{*}{ Gender } & Male & 48 & 77.4 & \multirow{2}{*}{1.2258} & \multirow{2}{*}{0.42153} \\
\hline & Female & 14 & 22.6 & & \\
\hline \multirow{3}{*}{ Educational Level } & Intermediate education and less & 3 & 4.8 & \multirow{3}{*}{2.8226} & \multirow{3}{*}{0.49668} \\
\hline & Upper intermediate education & 5 & 8.1 & & \\
\hline & High education & 54 & 87.1 & & \\
\hline \multirow{4}{*}{$\begin{array}{l}\text { Monthly Household } \\
\text { Income Level }\end{array}$} & Less than 3000 Dollars & 0 & 0 & \multirow{4}{*}{3.4194} & \multirow{4}{*}{0.77984} \\
\hline & 3000 to $<4500$ Dollars & 11 & 17.7 & & \\
\hline & 4500 to $<6000$ Dollars & 14 & 22.6 & & \\
\hline & More than 6000 Dollars & 37 & 59.7 & & \\
\hline \multirow{5}{*}{ Marital Status } & Single & 11 & 17.7 & \multirow{5}{*}{3.0806} & \multirow{5}{*}{1.49643} \\
\hline & Married & 14 & 22.6 & & \\
\hline & Divorced & 15 & 24.2 & & \\
\hline & Widowed & 3 & 4.8 & & \\
\hline & In a relation & 19 & 30.6 & & \\
\hline \multirow{2}{*}{ Origin } & Western cultures & 52 & 83.9 & \multirow{2}{*}{1.1613} & \multirow{2}{*}{0.37080} \\
\hline & Eastern cultures & 10 & 16.1 & & \\
\hline
\end{tabular}


Table 2. Attitude of research sample toward siwa local cuisine.

\begin{tabular}{|c|c|c|c|c|c|}
\hline Sentences & Choices & $\mathbf{F}$ & $\%$ & Mean & $\begin{array}{l}\text { Std. } \\
\text { Deviation }\end{array}$ \\
\hline \multirow{2}{*}{$\begin{array}{l}\text { Is this your first time } \\
\text { visiting Siwa? }\end{array}$} & Yes & 32 & 51.6 & \multirow{2}{*}{1.4839} & \multirow{2}{*}{0.50382} \\
\hline & No & 30 & 48.4 & & \\
\hline \multirow{3}{*}{$\begin{array}{l}\text { Have you previously } \\
\text { eaten any food items } \\
\text { that belongs Siwa's } \\
\text { cuisine? }\end{array}$} & Yes & 31 & 50 & \multirow{3}{*}{1.5806} & \multirow{3}{*}{0.64142} \\
\hline & No & 26 & 41.9 & & \\
\hline & May be & 5 & 8.1 & & \\
\hline \multirow{4}{*}{$\begin{array}{l}\text { I think trying Siwa local } \\
\text { food is a memorable } \\
\text { food experience. }\end{array}$} & Yes & 32 & 51.6 & \multirow{4}{*}{1.4839} & \multirow{4}{*}{0.50382} \\
\hline & No & 30 & 48.4 & & \\
\hline & Trying different tastes & 17 & 27.4 & & \\
\hline & Escaping from routine & 16 & 25.8 & & \\
\hline \multirow{5}{*}{$\begin{array}{l}\text { The major reason that } \\
\text { may encourage you to } \\
\text { eat Siwa local food is: } \\
\text { (please choose the } \\
\text { most important one). }\end{array}$} & Trying authentic experiences & 21 & 33.9 & \multirow{4}{*}{2.3710} & \multirow{3}{*}{1.11963} \\
\hline & Discovering un-familiar ingredients & 5 & 8.1 & & \\
\hline & $\begin{array}{l}\text { Experiencing new styles of food } \\
\text { presentation }\end{array}$ & 3 & 4.8 & & \\
\hline & $\begin{array}{l}\text { Discovering un-familiar cooking } \\
\text { methods }\end{array}$ & 0 & 0 & & \\
\hline & Escaping from routine & 15 & 24.2 & \multirow{6}{*}{2.6613} & \multirow{6}{*}{1.47040} \\
\hline \multirow{5}{*}{$\begin{array}{l}\text { The major reason that } \\
\text { may encourage you to } \\
\text { eat in Siwa local } \\
\text { restaurants is: } \\
\text { (please choose the } \\
\text { most important one). }\end{array}$} & Trying authentic experiences & 21 & 33.9 & & \\
\hline & $\begin{array}{l}\text { Experiencing pleasant ambience and } \\
\text { atmosphere }\end{array}$ & 8 & 12.9 & & \\
\hline & $\begin{array}{l}\text { Entertaining unique design, décor } \\
\text { and layout }\end{array}$ & 8 & 12.9 & & \\
\hline & Discovering culture & 8 & 12.9 & & \\
\hline & Dealing with local people & 2 & 3.2 & & \\
\hline
\end{tabular}

to eat Siwa local food, no one chooses discovering un-familiar cooking methods among reasons. Trying authentic experiences was ranked first (33.9\%). The rest of reasons come in the following order: Trying different tastes (27.4\%), escaping from routine $(25.8 \%)$, discovering un-familiar ingredients $(8.1 \%)$ and experiencing new styles of food presentation (4.8\%).

In regards to the major reasons that might encourage the respondent to eat in Siwa local restaurants, trying authentic experiences (33.9\%) comes as the major reason that might encourage the respondent to eat in Siwa local restaurants, followed by escaping from routine (24.2\%). Experiencing pleasant ambience and atmosphere, entertaining unique design, décor and layout and discovering culture were ranked third (12.9\%). Dealing with local people (3.2\%) came at the end of the ranking.

\subsubsection{Interest in Local Food during Travelling among Research Sample} In regards to interest in local food during travelling among research sample as shown in Table 3, the highest percentage of respondents (79\%) referred that they 
are thinking much about food when travelling. They indicated that their food choices are very important during their trips. More than half of them (56.4\%) referred that the availability of different types of cuisine at the destination is important when choosing it as they believed that food and eating experiences are important in choosing a touristic destination. They are looking at food as an important motivator for travelling. Therefore, trying local food in the hosting destination is an important aspect of the overall touristic experience.

$72.6 \%$ of respondents indicated that collecting information about both local restaurants and local food traditions before travelling are important. 58\% refereed that their dining experiences are important to overall satisfactory of the trip as trying local food is a memorable food experience and $54.8 \%$ mentioned that experiencing food and beverage at a destination help create amazing impression thus make more than half of respondents (51.6\%) to be purposefully dine at restaurants offering local/regional foods.

Table 3. Interest in local food during travelling among research sample.

\begin{tabular}{|c|c|c|c|c|c|c|c|c|c|c|}
\hline \multirow{2}{*}{$\begin{array}{l}\text { Interest in local food during travelling } \\
\text { among research sample }\end{array}$} & \multicolumn{4}{|l|}{ Choice } & & \multicolumn{3}{|c|}{$\begin{array}{l}\text { Central Tendency } \\
\text { Measures }\end{array}$} & \multicolumn{2}{|l|}{$\begin{array}{l}\text { Dispersion } \\
\text { Measures }\end{array}$} \\
\hline & $\begin{array}{l}\text { Strongly } \\
\text { Disagree }\end{array}$ & Disagree & Neutral & Agree & $\begin{array}{l}\text { Strongly } \\
\text { Agree }\end{array}$ & Mean & Median & Mode & $\begin{array}{l}\text { Std. } \\
\text { Deviation }\end{array}$ & Range \\
\hline When travelling, I think much about food. & $\begin{array}{l}1 \\
1.6\end{array}$ & $\begin{array}{l}6 \\
9.7\end{array}$ & $\begin{array}{l}6 \\
9.7\end{array}$ & $\begin{array}{l}22 \\
35.5\end{array}$ & $\begin{array}{l}27 \\
43.5\end{array}$ & 4.0968 & 4 & 5 & 1.03559 & 4 \\
\hline $\begin{array}{l}\text { During my trips, my food choices are very } \\
\text { important. }\end{array}$ & $\begin{array}{l}1 \\
1.6\end{array}$ & $\begin{array}{l}6 \\
9.7\end{array}$ & $\begin{array}{l}6 \\
9.7\end{array}$ & $\begin{array}{l}22 \\
35.5\end{array}$ & $\begin{array}{l}27 \\
43.5\end{array}$ & 4.0968 & 4 & 5 & 1.03559 & 4 \\
\hline $\begin{array}{l}\text { The availability of different types of cuisine } \\
\text { at a hosting destination is important to me } \\
\text { when choosing it. }\end{array}$ & $\begin{array}{l}5 \\
8.1\end{array}$ & $\begin{array}{l}6 \\
9.7\end{array}$ & $\begin{array}{l}16 \\
25.8\end{array}$ & $\begin{array}{l}25 \\
40.3\end{array}$ & $\begin{array}{l}10 \\
16.1\end{array}$ & 3.4677 & 4 & 4 & 1.12669 & 4 \\
\hline $\begin{array}{l}\text { When travelling, I think it is important to } \\
\text { try local food in the hosting destination. }\end{array}$ & $\begin{array}{l}2 \\
3.2\end{array}$ & $\begin{array}{l}9 \\
14.5\end{array}$ & $\begin{array}{l}16 \\
25.8\end{array}$ & $\begin{array}{l}25 \\
40.3\end{array}$ & $\begin{array}{l}10 \\
16.1\end{array}$ & 3.5161 & 4 & 4 & 1.03610 & 4 \\
\hline $\begin{array}{l}\text { I think food is an important motivator for } \\
\text { travelling. }\end{array}$ & $\begin{array}{l}5 \\
8.1\end{array}$ & $\begin{array}{l}6 \\
9.7\end{array}$ & $\begin{array}{l}16 \\
25.8\end{array}$ & $\begin{array}{l}25 \\
40.3\end{array}$ & $\begin{array}{l}10 \\
16.1\end{array}$ & 3.4677 & 4 & 4 & 1.12669 & 4 \\
\hline $\begin{array}{l}\text { I think food and eating experiences are } \\
\text { important in choosing a destination. }\end{array}$ & $\begin{array}{l}5 \\
8.1\end{array}$ & $\begin{array}{l}6 \\
9.7\end{array}$ & $\begin{array}{l}16 \\
25.8\end{array}$ & $\begin{array}{l}25 \\
40.3\end{array}$ & $\begin{array}{l}10 \\
16.1\end{array}$ & 3.4677 & 4 & 4 & 1.12669 & 4 \\
\hline $\begin{array}{l}\text { I interest in collecting information about local } \\
\text { food traditions before travelling. }\end{array}$ & $\begin{array}{l}5 \\
8.1\end{array}$ & $\begin{array}{l}6 \\
9.7\end{array}$ & $\begin{array}{l}6 \\
9.7\end{array}$ & $\begin{array}{l}24 \\
38.7\end{array}$ & $\begin{array}{l}21 \\
33.9\end{array}$ & 3.8065 & 4 & 4 & 1.23923 & 4 \\
\hline $\begin{array}{l}\text { I think collecting information about local } \\
\text { restaurants before travelling is important. }\end{array}$ & $\begin{array}{l}5 \\
8.1\end{array}$ & $\begin{array}{l}6 \\
9.7\end{array}$ & $\begin{array}{l}6 \\
9.7\end{array}$ & $\begin{array}{l}24 \\
38.7\end{array}$ & $\begin{array}{l}21 \\
33.9\end{array}$ & 3.8065 & 4 & 4 & 1.23923 & 4 \\
\hline $\begin{array}{l}\text { My dining experiences are important to overall } \\
\text { satisfactory of my trip. }\end{array}$ & $\begin{array}{l}5 \\
8.1\end{array}$ & $\begin{array}{l}6 \\
9.7\end{array}$ & $\begin{array}{l}15 \\
24.2\end{array}$ & $\begin{array}{l}26 \\
41.9\end{array}$ & $\begin{array}{l}10 \\
16.1\end{array}$ & 3.4839 & 4 & 4 & 1.12704 & 4 \\
\hline $\begin{array}{l}\text { I purposefully dine at restaurants offering } \\
\text { local/regional foods. }\end{array}$ & $\begin{array}{l}2 \\
3.2\end{array}$ & $\begin{array}{l}8 \\
12.9\end{array}$ & $\begin{array}{l}18 \\
29\end{array}$ & $\begin{array}{l}24 \\
38.7\end{array}$ & $\begin{array}{l}10 \\
16.1\end{array}$ & 3.5161 & 4 & 4 & 1.02016 & 4 \\
\hline $\begin{array}{l}\text { Experiencing food and beverage at a travel } \\
\text { destination help create amazing impression } \\
\text { of a destination. }\end{array}$ & $\begin{array}{l}5 \\
8.1\end{array}$ & $\begin{array}{l}4 \\
6.4\end{array}$ & $\begin{array}{l}21 \\
33.9\end{array}$ & $\begin{array}{l}23 \\
37.1\end{array}$ & $\begin{array}{l}9 \\
14.5\end{array}$ & 3.4355 & 4 & 4 & 1.08069 & 4 \\
\hline
\end{tabular}




\subsubsection{Intention to Try Siwa Local Food among Respondents}

Depending on the data of Table 4, more than half of respondents (51.6\%) are interested in asking about Siwa local food to try. The majority of them preferred to dine at places that give them the chances to meet Siwa local people (75.8\%) and to experience Siwa local culture (80.7\%). During their visit to Siwa, $51.6 \%$ of respondents preferred to avoid food that is similar to what they eat at homes, $54.8 \%$ interested in trying food items that prepared with local ingredients and prepared with local cooking methods and techniques. The majority of them (83.9\%) interested in experiencing a new food that reflected Siwa local culture.

\subsubsection{Behavioral Intention toward Siwa Local Food Experience}

As shown in Table 5, and in regards to behavioral intention toward Siwa local food experience among research sample, satisfaction about Siwa local food experience motivates $70.6 \%$ of respondents to try the same food items, the same cooking styles and the same ingredients in their homes. It motivates them to search the same food items in their home country and to visit restaurants serving the same cuisine when return homes (If available). Satisfaction about Siwa local food experience might motivate respondents to return again to Siwa to retry the same local food (59.7\%), to interest in recording this local food experiences by videos and photos to share with friends through social media $(80.7 \%)$, to advice others to try it (83.9\%) and to share such an experience with others $(82.3 \%)$.

Table 4. Intention to try Siwa local food among research sample.

\begin{tabular}{|c|c|c|c|c|c|c|c|c|c|c|}
\hline \multirow{2}{*}{$\begin{array}{l}\text { Intention to try Siwa local food } \\
\text { among research sample }\end{array}$} & \multicolumn{5}{|l|}{ Choice } & \multicolumn{3}{|c|}{ Central Tendency Measures } & \multicolumn{2}{|c|}{$\begin{array}{l}\text { Dispersion } \\
\text { Measures }\end{array}$} \\
\hline & $\begin{array}{l}\text { Strongly } \\
\text { Disagree }\end{array}$ & Disagree & Neutral & Agree & $\begin{array}{l}\text { Strongly } \\
\text { Agree }\end{array}$ & Mean & Median & Mode & $\begin{array}{l}\text { Std. } \\
\text { Deviation }\end{array}$ & Range \\
\hline $\begin{array}{l}\text { I interested in asking about Siwa } \\
\text { local food to try. }\end{array}$ & $\begin{array}{l}5 \\
8.1\end{array}$ & $\begin{array}{l}4 \\
6.4\end{array}$ & $\begin{array}{l}21 \\
33.9\end{array}$ & $\begin{array}{l}23 \\
37.1\end{array}$ & $\begin{array}{l}9 \\
14.5\end{array}$ & 3.4355 & 4 & 4 & 1.08069 & 4 \\
\hline $\begin{array}{l}\text { If possible, I prefer to dine at places } \\
\text { that give me a chance to meet Siwa } \\
\text { local people. }\end{array}$ & $\begin{array}{l}1 \\
1.6\end{array}$ & $\begin{array}{l}6 \\
9.7\end{array}$ & $\begin{array}{l}8 \\
12.9\end{array}$ & $\begin{array}{l}34 \\
54.8\end{array}$ & $\begin{array}{l}13 \\
21\end{array}$ & 3.8387 & 4 & 4 & 0.92672 & 4 \\
\hline $\begin{array}{l}\text { If possible, I prefer to dine at places } \\
\text { that give me a chance to experience } \\
\text { Siwa local culture. }\end{array}$ & $\begin{array}{l}1 \\
1.6\end{array}$ & $\begin{array}{l}5 \\
8.1\end{array}$ & $\begin{array}{l}6 \\
9.7\end{array}$ & $\begin{array}{l}35 \\
56.5\end{array}$ & $\begin{array}{l}15 \\
24.2\end{array}$ & 3.9355 & 4 & 4 & 0.90302 & 4 \\
\hline $\begin{array}{l}\text { During my visit to Siwa, I prefer to avoid } \\
\text { food that is similar to what I } \\
\text { eat at home. }\end{array}$ & $\begin{array}{l}5 \\
8.1\end{array}$ & $\begin{array}{l}4 \\
6.4\end{array}$ & $\begin{array}{l}21 \\
33.9\end{array}$ & $\begin{array}{l}23 \\
37.1\end{array}$ & $\begin{array}{l}9 \\
14.5\end{array}$ & 3.4355 & 4 & 4 & 1.08069 & 4 \\
\hline $\begin{array}{l}\text { During my visit to Siwa, I interested } \\
\text { in trying food items that prepared } \\
\text { with local ingredients. }\end{array}$ & $\begin{array}{l}5 \\
8.1\end{array}$ & $\begin{array}{l}4 \\
6.4\end{array}$ & $\begin{array}{l}19 \\
30.6\end{array}$ & $\begin{array}{l}25 \\
40.3\end{array}$ & $\begin{array}{l}9 \\
14.5\end{array}$ & 3.4677 & 4 & 4 & 1.08216 & 4 \\
\hline $\begin{array}{l}\text { During my visit to Siwa, I interested } \\
\text { in trying food items that prepared } \\
\text { with local cooking methods and } \\
\text { techniques. }\end{array}$ & $\begin{array}{l}4 \\
6.4\end{array}$ & $\begin{array}{l}5 \\
8.1\end{array}$ & $\begin{array}{l}19 \\
30.6\end{array}$ & $\begin{array}{l}25 \\
40.3\end{array}$ & $\begin{array}{l}9 \\
14.5\end{array}$ & 3.4839 & 4 & 4 & 1.05180 & 4 \\
\hline $\begin{array}{l}\text { I interested in experiencing a new } \\
\text { food that reflected Siwa local culture. }\end{array}$ & $\begin{array}{l}1 \\
1.6\end{array}$ & $\begin{array}{l}5 \\
8.1\end{array}$ & $\begin{array}{l}4 \\
6.4\end{array}$ & $\begin{array}{l}36 \\
58.1\end{array}$ & $\begin{array}{l}16 \\
25.8\end{array}$ & 3.9839 & 4 & 4 & 0.89611 & 4 \\
\hline
\end{tabular}


Table 5. Behavioral intention toward Siwa local food experience.

\begin{tabular}{|c|c|c|c|c|c|c|c|c|c|c|}
\hline \multirow{2}{*}{$\begin{array}{l}\text { Behavioral intention toward Siwa } \\
\text { local food experience among } \\
\text { research sample }\end{array}$} & \multicolumn{5}{|l|}{ Choice } & \multicolumn{3}{|c|}{$\begin{array}{l}\text { Central Tendency } \\
\text { Measures }\end{array}$} & \multicolumn{2}{|c|}{$\begin{array}{l}\text { Dispersion } \\
\text { Measures }\end{array}$} \\
\hline & $\begin{array}{l}\text { Strongly } \\
\text { Disagree }\end{array}$ & Disagree & Neutral & Agree & $\begin{array}{l}\text { Strongly } \\
\text { Agree }\end{array}$ & Mean & Median & Mode & $\begin{array}{l}\text { Std. } \\
\text { Deviation }\end{array}$ & Range \\
\hline $\begin{array}{l}\text { Satisfaction about Siwa local food } \\
\text { experience motivates me to try the } \\
\text { same food items in my home. }\end{array}$ & $\begin{array}{l}2 \\
3.2\end{array}$ & $\begin{array}{l}3 \\
4.8\end{array}$ & $\begin{array}{l}13 \\
21\end{array}$ & $\begin{array}{l}28 \\
44.8\end{array}$ & $\begin{array}{l}16 \\
25.8\end{array}$ & 3.8548 & 4 & 4 & 0.97252 & 4 \\
\hline $\begin{array}{l}\text { Satisfaction about Siwa local food } \\
\text { experience motivates me to try the } \\
\text { same cooking styles in my home. }\end{array}$ & $\begin{array}{l}2 \\
3.2\end{array}$ & $\begin{array}{l}6 \\
9.7\end{array}$ & $\begin{array}{l}10 \\
16.1\end{array}$ & $\begin{array}{l}29 \\
46.4\end{array}$ & $\begin{array}{l}15 \\
24.2\end{array}$ & 3.7903 & 4 & 4 & 1.02649 & 4 \\
\hline $\begin{array}{l}\text { Satisfaction about Siwa local food } \\
\text { experience motivates me to try the } \\
\text { same ingredients at my own home. }\end{array}$ & $\begin{array}{l}2 \\
3.2\end{array}$ & $\begin{array}{l}3 \\
4.8\end{array}$ & $\begin{array}{l}13 \\
21\end{array}$ & $\begin{array}{l}29 \\
46.4\end{array}$ & $\begin{array}{l}15 \\
24.2\end{array}$ & 3.8387 & 4 & 4 & 0.96145 & 4 \\
\hline $\begin{array}{l}\text { Satisfaction about Siwa local food } \\
\text { experience motivates me to search the } \\
\text { same food items in my home country. }\end{array}$ & $\begin{array}{l}2 \\
3.2\end{array}$ & $\begin{array}{l}6 \\
9.7\end{array}$ & $\begin{array}{l}10 \\
16.1\end{array}$ & $\begin{array}{l}28 \\
44.8\end{array}$ & $\begin{array}{l}16 \\
25.8\end{array}$ & 3.8065 & 4 & 4 & 1.03763 & 4 \\
\hline $\begin{array}{l}\text { Satisfaction about Siwa local foods } \\
\text { motivates me to visit restaurants } \\
\text { serving the same cuisine when I return } \\
\text { home (If available). }\end{array}$ & $\begin{array}{l}2 \\
3.2\end{array}$ & $\begin{array}{l}6 \\
9.7\end{array}$ & $\begin{array}{l}10 \\
16.1\end{array}$ & $\begin{array}{l}28 \\
44.8\end{array}$ & $\begin{array}{l}16 \\
25.8\end{array}$ & 3.8065 & 4 & 4 & 1.03763 & 4 \\
\hline $\begin{array}{l}\text { Satisfaction about Siwa local food } \\
\text { experience motivates me to return } \\
\text { again to the destination to retry the } \\
\text { same local food. }\end{array}$ & $\begin{array}{l}8 \\
12.9\end{array}$ & $\begin{array}{l}1 \\
1.6\end{array}$ & $\begin{array}{l}16 \\
25.8\end{array}$ & $\begin{array}{l}24 \\
38.7\end{array}$ & $\begin{array}{l}13 \\
21\end{array}$ & 3.5323 & 4 & 4 & 1.22431 & 4 \\
\hline $\begin{array}{l}\text { I interested in recording my local } \\
\text { food experiences in Siwa by videos } \\
\text { and photos to share with my friends } \\
\text { through social media. }\end{array}$ & $\begin{array}{l}1 \\
1.6\end{array}$ & $\begin{array}{l}5 \\
8.1\end{array}$ & $\begin{array}{l}6 \\
9.7\end{array}$ & $\begin{array}{l}35 \\
56.5\end{array}$ & $\begin{array}{l}15 \\
24.2\end{array}$ & 3.9355 & 4 & 4 & 0.90302 & 4 \\
\hline $\begin{array}{l}\text { Satisfaction about Siwa local food } \\
\text { motivates me to advice others to try it. }\end{array}$ & $\begin{array}{l}0 \\
0\end{array}$ & $\begin{array}{l}4 \\
6.4\end{array}$ & $\begin{array}{l}6 \\
9.7\end{array}$ & $\begin{array}{l}37 \\
59.7\end{array}$ & $\begin{array}{l}15 \\
24.2\end{array}$ & 4.0161 & 4 & 4 & 0.77865 & 3 \\
\hline $\begin{array}{l}\text { Satisfaction about Siwa local foods } \\
\text { motivates me to share such an } \\
\text { experience with others. }\end{array}$ & $\begin{array}{l}1 \\
1.6\end{array}$ & $\begin{array}{l}2 \\
3.2\end{array}$ & $\begin{array}{l}8 \\
12.9\end{array}$ & $\begin{array}{l}36 \\
58.1\end{array}$ & $\begin{array}{l}15 \\
24.2\end{array}$ & 4 & 4 & 4 & 0.80978 & 4 \\
\hline
\end{tabular}

\subsection{Data Analysis}

Data analysis is summarized in testing the research hypotheses as follows.

\subsection{1. $\mathrm{H}_{1}$ : Good Memorable Local Food Experience in Hosting Destination Impacts Positively on Tourist's Using of the Same Food Items and Cooking Styles in Their Homes}

By using Linear Simple Regression Analysis, the results showed that there is a statistical significant effect (P-value $=0.002)$ of good memorable local food experience on respondent's desire to use the same food and cooking styles at home. This means that satisfaction about local food experience in hosting destination motivates tourists to use the same food items and cooking styles in their homes (See Table 6). By calculating Regression Coefficient $(\beta=0.196)$, the results indicated that any increasing in satisfaction rate by one unit will positively impacts the respondent's behavior intention to use the same food items and cooking styles in their homes by 0.196 unit. Thus, the research accepts the 1st hypothesis. 
Table 6. Linear Simple Regression Analysis to test the 1st hypothesis.

\begin{tabular}{|c|c|c|c|c|c|c|}
\hline \multirow[t]{2}{*}{ Statement } & \multirow[t]{2}{*}{$\begin{array}{l}\mathrm{R} \\
\text { Coefficient of } \\
\text { correlation }\end{array}$} & \multirow{2}{*}{$\begin{array}{l}\mathbf{R}^{2} \\
\text { The coefficient } \\
\text { of determination }\end{array}$} & \multirow[t]{2}{*}{ F } & \multirow[t]{2}{*}{ Sig. } & \multicolumn{2}{|l|}{$\begin{array}{l}\beta \\
\text { Regression } \\
\text { Coefficient }\end{array}$} \\
\hline & & & & & Variable & Coefficient \\
\hline & & & & 0.000 & Constant & 2.235 \\
\hline $\begin{array}{l}\text { Good } \\
\text { memorable } \\
\text { local food } \\
\text { experience }\end{array}$ & 0.382 & 0.146 & 10.247 & 0.002 & $\begin{array}{l}\text { Using the } \\
\text { same food } \\
\text { and cooking } \\
\text { styles at } \\
\text { homes }\end{array}$ & $-0.196-$ \\
\hline
\end{tabular}

\subsection{2. $\mathrm{H}_{2}$ : Good Memorable Local Food Experience in Hosting Destination} Impacts Positively on Tourist's Searching the Same Food Items in Their Home Countries

According to data illustrated in Table 7, the results of Linear Simple Regression Analysis showed a statistically significant impact $(\mathrm{P}$-value $=0.002)$ of the good memorable local food experience on respondent's desire to search the same food in home countries. This means that the satisfaction about local food experience in hosting destination motivates tourists to search the same food in home countries. By calculating Regression Coefficient $(\beta=0.186)$, it indicated that any increase of the satisfaction by one unit will positively impacts the respondent's behavior intention to search the same food in home countries by 0.186 unit. Thus, the research accepts the 2 nd hypothesis.

\subsection{3. $\mathrm{H}_{3}$ : Good Memorable Local Food Experience in Hosting Destination Impacts Positively on Tourist's Dining in Restaurants That Serve These Items}

Depending on the data of Table 8, Linear Simple Regression Analysis results showed a statistically significant impact $(\mathrm{P}$-value $=0.002)$ of the good memorable local food experience on respondent's desire to dine in restaurants that serve local items. By calculating Regression Coefficient $(\beta=0.186)$, the results indicated that any increase in the satisfaction by one unit will positively impacts the respondent's behavior intention to dine in restaurants that serve local food items by 0.186 unit. Thus, the research accepts the $3^{\text {rd }}$ hypothesis.

\subsection{4. $\mathrm{H}_{4}$ : Good Memorable Local Food Experience in Hosting Destination Impacts Positively on Tourist's Returning Again to the Destination to Retry the Same Local Food}

By using Linear Simple Regression Analysis as shown in Table 9, there is a statistically significant impact $(\mathrm{P}$-value $=0.006)$ of the good memorable local food experience on the respondent's desire to return again to the destination to retry the same local food. Regression Coefficient $(\beta=0.142)$ indicated that any increase of the satisfaction level by one unit will positively impacts the respondent's behavior intention to return again to the destination to retry the same local food by 0.142 unit. Thus, the research accepts the 4 th hypothesis. 
Table 7. Linear Simple Regression Analysis to test the 2nd hypothesis.

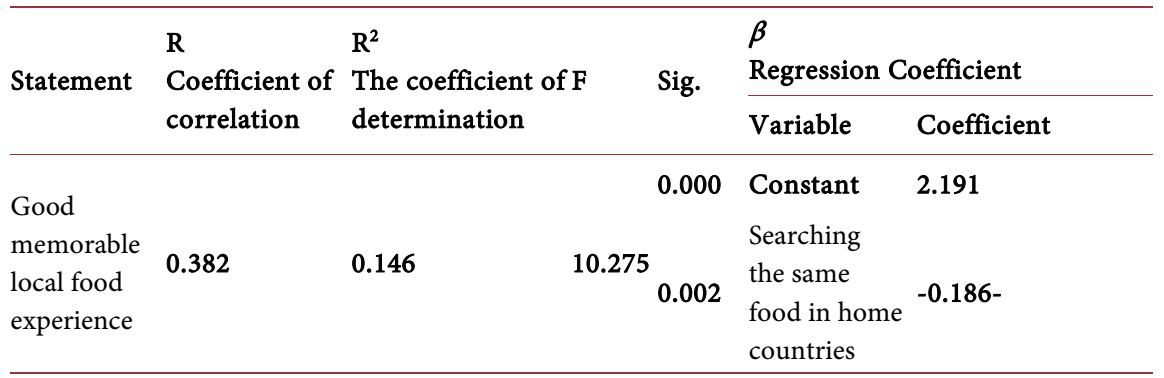

Table 8. Linear Simple Regression Analysis to test the 3rd hypothesis.

\begin{tabular}{|c|c|c|c|c|c|c|}
\hline \multirow[t]{2}{*}{ Statement } & \multirow{2}{*}{$\begin{array}{l}\text { R } \\
\text { Coefficient of } \\
\text { correlation }\end{array}$} & \multirow{2}{*}{\multicolumn{2}{|c|}{$\begin{array}{l}\mathrm{R}^{2} \\
\text { The coefficient of } \mathrm{F} \\
\text { determination }\end{array}$}} & \multirow[t]{2}{*}{ Sig. } & \multicolumn{2}{|c|}{$\begin{array}{l}\beta \\
\text { Regression Coefficient }\end{array}$} \\
\hline & & & & & Variable & Coefficient \\
\hline $\begin{array}{l}\text { Good } \\
\text { memorable } \\
\text { local food } \\
\text { experience }\end{array}$ & 0.382 & 0.146 & 10.275 & 0.000 & $\begin{array}{l}\text { Constant } \\
\text { Dining in } \\
\text { restaurants } \\
\text { that serve } \\
\text { these items }\end{array}$ & $-0.186-$ \\
\hline
\end{tabular}

Table 9. Linear Simple Regression Analysis to test the 4th hypothesis.

\begin{tabular}{|c|c|c|c|c|c|c|}
\hline \multirow{2}{*}{ Statement } & \multirow{2}{*}{$\begin{array}{l}\mathrm{R} \\
\text { Coefficient of } \\
\text { correlation }\end{array}$} & \multirow{2}{*}{$\begin{array}{l}\mathbf{R}^{2} \\
\text { The coefficient of } \\
\text { determination }\end{array}$} & \multirow{2}{*}{ F } & \multirow{2}{*}{ Sig. } & \multicolumn{2}{|c|}{$\begin{array}{l}\beta \\
\text { Regression Coefficient }\end{array}$} \\
\hline & & & & & Variable & Coefficient \\
\hline $\begin{array}{l}\text { Good } \\
\text { memorable } \\
\text { local food } \\
\text { experience }\end{array}$ & 0.345 & 0.119 & 8.087 & 0.000 & $\begin{array}{l}\text { Constant } \\
\text { Returning } \\
\text { again to retry } \\
\text { the same local } \\
\text { food }\end{array}$ & $-0.142-$ \\
\hline
\end{tabular}

5.2.5. $\mathrm{H}_{5}$ : Good Memorable Local Food Experience in Hosting Destination Impacts Positively on Tourist's Sharing Their Experiences to Motivate Others to Try Such Local Food

According to Table 10, the results of Linear Simple Regression Analysis showed no statistical significant impact $(\mathrm{P}$-value $=0.065)$ of the good memorable local food experience on the respondent's desire to share their experiences to motivate others to try local food. This means that increasing the satisfaction level among respondents have no impact on their behavior intentions to share their experiences to motivate others to try local food. Thus, the research rejects the 5th hypothesis.

\subsection{The Promotional Framework of Siwa Local Food}

Depending on the results, the research verifies the major opportunities of Siwa oasis local cuisine that could be used in purpose of supporting the tourism demand for the oasis. These opportunities are analyzed carefully and to provide an integrated framework of international promotional plan of Siwa local food. This integrated framework is illustrated in Table 11. 
Table 10. Linear Simple Regression Analysis to test the 5th hypothesis.

\begin{tabular}{|c|c|c|c|c|c|c|}
\hline \multirow{2}{*}{ Statement } & \multirow{2}{*}{$\begin{array}{l}\mathrm{R} \\
\text { Coefficient of } \\
\text { correlation }\end{array}$} & \multirow{2}{*}{$\begin{array}{l}\mathrm{R}^{2} \\
\text { The coefficient of } \\
\text { determination }\end{array}$} & \multirow{2}{*}{ F } & \multirow{2}{*}{ Sig. } & \multicolumn{2}{|c|}{$\begin{array}{l}\beta \\
\text { Regression Coefficient }\end{array}$} \\
\hline & & & & & Variable & Coefficient \\
\hline $\begin{array}{l}\text { Good } \\
\text { memorable } \\
\text { local food } \\
\text { experience }\end{array}$ & 0.235 & 0.055 & 3.520 & 0.000 & $\begin{array}{l}\text { Constant } \\
\text { Sharing their } \\
\text { experiences to } \\
\text { motivate others } \\
\text { to try local food }\end{array}$ & $-0.147-$ \\
\hline
\end{tabular}

Table 11. The integrated framework for international promotional plan of Siwa local food.

\begin{tabular}{ll}
\hline Exposure Opportunity & Food Experience \\
\hline $\begin{array}{l}\text { Away from Siwa } \\
\text { the main tourists' exporting }\end{array}$ & $\begin{array}{l}\text { countries to ensure the } \\
\text { pre-travel exposure for the } \\
\text { majority of potential tourists. }\end{array}$ \\
& \\
Away from Siwa & $\begin{array}{l}\text { Exploiting the opportunity } \\
\text { of tourist presence in the } \\
\text { (During the Trip to }\end{array}$ \\
Siwa Destination) & $\begin{array}{l}\text { display the most prominent } \\
\text { local Siwa food product. }\end{array}$
\end{tabular}

\section{Practices}

- A number of taste festivals were held for the local Siwa food product in Egyptian embassies and consulates for foreigners outside Egypt can be a good solution.

- Produce a series of short promotional films about the local Siwi food products and display it in the means of transportation that bring tourists to the destination.

- Providing free samples of the most famous food products for tourists coming to Siwa destination in the means of transportation. These food samples should be prepared carefully and under strict health supervision to be produced and distributed under the supervision of the governorate.

- Providing free food tasting samples in different areas in Siwa destination that is frequently visited by tourists.

At Siwa Destination (During the Trip in Siwa Destination)

Away from Siwa (During the Trip from Siwa to Home Country) (At Home Country Again)
Pursuing the tourist during his stay in the Siwa tourist destination to display the local food product.
Exploiting the opportunity of tourist presence in the means of transportation to display the most prominent local Siwa food product again.
- Provide free samples of the local Siwa food products with any other food product requested by the tourist while his presence in the destination.

- Organizing tasting festivals for tourist groups coming to Siwa.

- Providing free samples of the local Siwa foods and offer promotional films on the most famous Siwa's food products.

- Conducting a number of surveys to collect the tourists' opinions toward the local siwa food products and toward the publicity style of such products.

Creating a database related to tourists who have previously visited Siwa to use it later in promoting the local foods to them in their homes.
- Sending of free samples of the local Siwa food products to those tourists in their homes at their special occasions such as birthdays, wedding anniversaries, etc.

Source: Prepared by the Author depending on research results. 


\section{Recommendations and Suggestions}

Depending on results, the research provides some recommendations and suggestions. While the research recommendations are related to all efforts that can be managed to increase the effectiveness of Siwa local food as a marketing tool of the integrated touristic product of Siwa oasis, the research suggestions are related to the future studies and researches that can emphasize on local food in general around the world.

\subsection{Recommendations}

According to results, the research provides the following recommendations:

- Siwa culinary festivals can be planned to link regional gastronomy to innovative food production styles to attract famous chefs and foodies from all over the world.

- Siwa slow food salon can be held in the presence of world famous characters.

- Siwa food fashion exhibition can be held to promote local food.

- Online Siwa food lovers' platform should be published.

- Innovate a new type of tourism that depending on culinary tours in Siwa oasis for those who seeking for more in-depth knowledge of Siwa's heritage and culture. These tours beginning with seeing the farming practices of local food ingredients, passing by local food items' processing, storage and other related stages to end by local food tasting and experience.

- Like tea and rice tours in china and tea tours in many Asian countries, Siwa can organize an international date tours and olive oil tours to illustrate the different practices of date and olive oil industries to explain the cultural and historical dimensions around date and olive oil.

\subsection{Suggestions}

Depending on research results, there is a need to achieve a series of studies and researches that related to local food in general. These studies are suggested to concentrate on the following fields and areas:

- The Impact of Globalization on Local Food Experiences: This research area is expected to concentrate on the positive and negative influences of globalization on local food spread.

- The Role of Authenticity in Adding Value to the Integrated Food Experiences: This research field is suggested to be about how to exploit heritage and authentic food ingredients, methods of preparation, styles and tools of presentation and décor pieces and motifs to develop the tourists' integrated food experiences.

- The Relation between Food Experience Authenticity and the Overall Tourist's Satisfaction: This research is about the contribution extent of food experience locality and authenticity in raising tourist's satisfaction levels.

- The Role of the Previous Local Food Experience in Directing Food Preferences among Tourists in Host Community: This research topic is re- 
lated to how person's tasting food items that related to any tourist destination would influence the same person's preference of such items when coming to this destination as a tourist in the future.

- Evaluation of Local Foods' Information Sources: It is about evaluating sources, both traditional and electronic, that supply tourists with information related to local food and how such sources intervenes in tourists awareness toward local food in a chosen destination.

- Using Food Events in Promoting Tourist Destinations: It relates to how to use the destination's local foods to develop special events in order to promote the destination and create a tourist demand on it.

- Studying the Role of Local Food Exhibitions in Inspiring Tourists to Try other Local Cuisine Items: It is about how local food exhibitions promote the food heritage in the way that motivates tourists to try other food items related to such a cuisine.

- Local Food and Sustainability: It concentrates on local food as an important tool that contributes of creating sustainability for tourism destination.

\section{Research Conclusion}

At any destination, local food represents a cultural image of this destination, reflecting many of its heritage dimensions, where local food plays a vital role in the visitor's interaction with the host community. Based on the different tourists' perceptions of local food, there are different levels of behavior towards this food. This study aimed at exploring the factors impacting the local food experience in Siwa Oasis as a unique tourist destination in Egypt, in order to know how to use local food as an attractive tool for tourism activity. The responses of 62 tourists, who are interested in Siwa Oasis, are gathered and analyzed to identify the degree of variation in their behavior towards local food provided in the oasis. The results showed no impact of good memorable local food experience in hosting destination on respondents' behavior intentions to share their experiences to motivate others to try local food. Other results showed statistically significant impact of such good memorable on respondents' behavior intentions to use the same food items and cooking styles in their homes, to search the same food items in their home countries, to dine in restaurants that serve these items and to return again to the destination to retry the same local food. Because of the limited number of the research sample, results couldn't be generalized to any other food items related to any other destination and reapplying the research to larger sample might lead to different results.

\section{Conflicts of Interest}

The author declares no conflicts of interest regarding the publication of this paper.

\section{References}

[1] Ryu, K. and Jang, S. (2006) Intention to Experience Local Cuisine in a Travel Desti- 
nation: The Modified Theory of Reasoned Action. Journal of Hospitality and Tourism Research, 30, 507-516. https://doi.org/10.1177/1096348006287163

[2] Mirtaghiyan, M.R., Gharibi, N. and Akbarnataj, H. (2013) A Study of Factors Influencing Food Tourism Branding: The Case of Iranian Tourism. American Journal of Tourism Management, 2, 63-68.

[3] Mason, M.C. and Paggiaro, A. (2015) Investigating the Role of Festival Scape in Culinary Tourism: The Case of Food and Wine Events. Tourism Management, 33, 1329-1336. https://doi.org/10.1016/j.tourman.2011.12.016

[4] Agrawal, S. (2017) Factors Affecting Tourist's Satisfaction Level at Religious Visit: A Study of Brij-Kshetra. International Journal of Applied Research, 3, 848-852.

[5] Amira, F. (2009) The Role of Local Food in Maldives Tourism: A Focus on Promotion and Economic Development. A Master Thesis of Philosophy in Tourism, Auckland University of Technology, New Zealand Tourism Research Institute (NZTRI), Auckland. https://core.ac.uk/download/pdf/56361515.pdf

[6] Ellis, A., Park, E., Kim, S. and Yeoman, I. (2018) What Is Food Tourism? Tourism Management, 68, 250-263. https://doi.org/10.1016/j.tourman.2018.03.025

[7] Shalini, D. and Duggal, S. (2015) A Review on Food Tourism Quality and Its Associated Forms around the World. African Journal of Hospitality, Tourism and Leisure, 4, 1-12.

[8] Kim, S. and Iwashita, C. (2016) Cooking Identity and Food Tourism: The Case of Japanese Udon Noodles. Tourism Recreation Research, 41, 89-100. https://doi.org/10.1080/02508281.2016.1111976

[9] Cankül, D. and Demir, I. (2018) Travel Agencies and Gastronomy Tourism: Case of IATA Member A-Class Travel Agencies. Journal of Gastronomy, Hospitality and Travel, 1, 3-10. https://doi.org/10.33083/joghat.2018.0

[10] Kim, Y.H., Duncan, J.L. and Jai, T.M. (2014) A Case Study of a Southern Food Festival: Using a Cluster Analysis Approach. Anatolia, 25, 457-473. https://doi.org/10.1080/13032917.2014.912245

[11] Okumus, B. and Cetin, G. (2018) Marketing Istanbul as a Culinary Destination. Journal of Destination Marketing and Management, 9, 340-346. https://doi.org/10.1016/j.jdmm.2018.03.008

[12] Hall, C.M. (2012) Boosting Food and Tourism-Related Regional Economic Development. In: OECD, Ed., Food and the Tourism Experience: The OECD-Korea Workshop, OECD Studies on Tourism, OECD Publishing, Paris, 49-62. https://doi.org/10.1787/9789264171923-4-en

[13] Yurtseven, H.R. and Kaya, O. (2011) Local Food in Local Menu: The Case of Gokceada, Tourismos. An International Multidisciplinary Journal of Tourism, 6, 263-275.

[14] Anna, S. (2017) An Exploratory Study of Food in Destination Marketing. Doctoral Thesis of Philosophy, Sheffield Hallam University, Sheffield. http://shura.shu.ac.uk/21927/1/Stalmirska_2018_PhD_ExploratoryStudyFood.pdf

[15] Sengel, T., Karagoz, A., Cetin, G., Dincer, F.I., Ertugral, S.M. and Balık, M. (2015) Tourists' Approach to Local Food. Procedia-Social and Behavioral Sciences, 195, 429-437. https://doi.org/10.1016/j.sbspro.2015.06.485

[16] Chen, C.-F. and Chen, F.-S. (2010) Experience Quality, Perceived Value, Satisfaction and Behavioral Intentions for Heritage Tourists. Tourism Management, 31, 29-35. https://doi.org/10.1016/j.tourman.2009.02.008

[17] Sheng, C.-W. and Chen, M.-C. (2012) A Study of Experience Expectations of Museum Visitors. Tourism Management, 33, 53-60. 
https://doi.org/10.1016/j.tourman.2011.01.023

[18] Sheng, C.-W. and Chen, M.-C. (2013) Tourist Experience Expectations: Questionnaire Development and Text Narrative Analysis. International Journal of Culture, Tourism and Hospitality Research, 7, 93-104. https://doi.org/10.1108/17506181311301390

[19] Ottenbacher, M.C. and Harrington, R.J. (2013) A Case Study of a Culinary Tourism Campaign in Germany Implications for Strategy Making and Successful Implementation. Journal of Hospitality and Tourism Research, 37, 3-28. https://doi.org/10.1177/1096348011413593

[20] Chang, R.C., Kivela, J. and Mak, A.H. (2011) Attributes that Influence the Evaluation of Travel Dining Experience: When East Meets West. Tourism Management, 32, 307-316. https://doi.org/10.1016/j.tourman.2010.02.009

[21] Mak, A.H., Lumbers, M., Eves, A. and Chang, R. (2013) An Application of the Repertory Grid Method and Generalized Procrustes Analysis to Investigate the Motivational Factors of Tourist Food Consumption. International Journal of Hospitality Management, 35, 327-338. https://doi.org/10.1016/j.ijhm.2013.07.007

[22] Kim, Y.G., Eves, A. and Scarles, C. (2013) Empirical Verification of a Conceptual Model of Local Food Consumption at a Tourist Destination. International Journal of Hospitality Management, 33, 484-489. https://doi.org/10.1016/j.ijhm.2012.06.005

[23] Namkung, Y. and Jang, S. (2007) Does Food Quality Really Matter in Restaurants? Its Impact on Customer Satisfaction and Behavioral Intentions. Journal of Hospitality and Tourism Research, 31, 387-410. https://doi.org/10.1177/1096348007299924

[24] Correia, A., Moital, M., Da Costa, C.F. and Peres, R. (2008) The Determinants of Gastronomic Tourists' Satisfaction: A Second-Order Factor Analysis. Journal of Foodservice, 19, 164-176. https://doi.org/10.1111/j.1745-4506.2008.00097.x

[25] Hohgi, H., Nagai, T. and Iriyam, A. (2014) Food Tourism in Thailand: Consumer Behaviors of Foreign Tourists in Thailand on Thai Food. Pipaboon Kururatchaikul Global Business Management. https://oatd.org/oatd/record?record=handle\%5C\%3A2065\%5C\%2F44429

[26] Hsu, F.-C. (2014) Food Tourism: Consumer Behavior in Relation to Traditional Food. Doctoral Thesis of Philosophy, Business School, the University of Queensland, Brisbane. https://espace.library.uq.edu.au/view/UQ:351471

[27] Wijaya, S. (2014) Encounters with Local Food: The Culinary Experiences of International Visitors in Indonesia. Doctoral Thesis of Marketing Management, College of Business, Victoria University, Melbourne. http://vuir.vu.edu.au/25865/1/Serli\%20Wijaya.pdf

[28] Horng, J.-S. and Tsai, C.-T. (2012) Culinary Tourism Strategic Development: An Asia-Pacific Perspective. International Journal of Tourism Research, 14, 40-55. https://doi.org/10.1002/jtr.834

[29] Jang, S., Liu, Y. and Namkung, Y. (2011) Effects on Authentic Atmospherics in Ethnic Restaurants: Investigating Chinese Restaurants. International Journal of Contemporary Hospitality Management, 23, 662-680. https://doi.org/10.1108/09596111111143395

[30] Qiu, H.Z., Yuan, J., Ye, B.H. and Hung, K. (2013) Wine Tourism Phenomena in China: An Emerging Market. International Journal of Contemporary Hospitality Management, 25, 1115-1134. https://doi.org/10.1108/IJCHM-06-2012-0087

[31] Sukalakamala, P. and Boyce, J.B. (2007) Customer Perceptions for Expectations and Acceptance of an Authentic Dining Experience in Thai Restaurants. Journal of 
Foodservice, 18, 69-75. https://doi.org/10.1111/j.1745-4506.2007.00048.x

[32] Batra, A. (2008) Foreign Tourists' Motivation and Information Source(s) Influencing Their Preference for Eating out at Ethnic Restaurants in Bangkok. International Journal of Hospitality and Tourism Administration, 9, 1-17. https://doi.org/10.1080/15256480801910178

[33] Cheung, S.C.H. (2008) Gastronomy and Tourism: A Case Study of Gourmet Country-Style Cuisine in Hong Kong. AOT, 4, 264-274. https://doi.org/10.4324/9780203891803.ch19

[34] Chuang, H.-T. (2009) The Rise of Culinary Tourism and Its Transformation of Food Cultures: The National Cuisine of Taiwan. The Copenhagen Journal of Asian Studies, 27, 84-108. https://doi.org/10.22439/cjas.v27i2.2542

[35] Chao, S.-C. (2010) Exploration of Local Food Selections in Lukang, Taiwan: Application of the Means-End Chain Theory. Doctoral Dissertation in Hospitality Administration, the Graduate Faculty of Texas Tech University, Lubbock. https://tu-ir.tdl.org/handle/2346/45275

[36] Duttagupta, S. (2013) Foreign Travelers' Recommendation of Culinary Tourism in India Based on Cuisine Image and Satisfaction with Experiences at Culinary Establishments: An Exploratory Study. Master Thesis of Environmental Studies, University of Waterloo, Waterloo.

https://uwspace.uwaterloo.ca/bitstream/handle/10012/7503/Duttagupta\%20Sudip.p df? sequence $=1$

[37] Henderson, J.C., Yun, O.S., Poon, P. and Biwei, X. (2012) Hawker Centers as Tourist Attractions: The Case of Singapore. International Journal of Hospitality Management, 31, 849-855. https://doi.org/10.1016/j.ijhm.2011.10.002

[38] Karim, S.A., Chua, B.-L. and Salleh, H. (2009) Malaysia as a Culinary Tourism Destination: International Tourists' Perspective. Journal of Tourism, Hospitality and Culinary Arts, 1, 63-78.

[39] Chi, C.G.-Q., Chua, B.L., Othman, M. and Karim, S.A. (2013) Investigating the Structural Relationships between Food Image, Food Satisfaction, Culinary Quality, and Behavioral Intentions: The Case of Malaysia. International Journal of Hospitality and Tourism Administration, 14, 99-120. https://doi.org/10.1080/15256480.2013.782215

[40] Astuti, M., Meliala, A., Dalais, F.S. and Wahlqvist, M.L. (2000) Tempe, a Nutritious and Healthy Food from Indonesia. Asia Pacific Journal of Clinical Nutrition, 9, 322-325. https://doi.org/10.1046/j.1440-6047.2000.00176.x

[41] Du Rand, G.E, Heath, E. and Alberts, N. (2003) The Role of Local and Regional Food in Destination Marketing: A South African Situation Analysis. Journal of Travel and Tourism Marketing, 14, 97-112. https://doi.org/10.1300/J073v14n03_06

[42] Amuquandoh, F.E. (2011) International Tourists' Concerns about Traditional Foods in Ghana. Journal of Hospitality and Tourism Management, 18, 1-9. https://doi.org/10.1375/jhtm.18.1.1

[43] Hjalager, A.M. and Richards, G. (2003) Still Undigested: Research Issues in Tourism and Gastronomy. In: Hjalager, A.M. and Richards, G., Eds., Tourism and Gastronomy, Rutledge, London, 400-422, Chapter 13.

https://doi.org/10.4324/9780203218617

[44] Yun, D., Hennessey, S.M. and MacDonald, R. (2011) Understanding Culinary Tourists: Segmentations Based on Past Culinary Experiences and Attitudes toward Food-Related Behaviour. International CHRIE Conference-Refereed Track. Paper 15. http://scholarworks.umass.edu/refereed/ICHRIE_2011/Friday/15 
[45] Pérez-Priego, M.A., García, M.B.G.-M., Gema Gomez-Casero, G. and Río, L.C.L. (2019) Segmentation Based on the Gastronomic Motivations of Tourists: The Case of the Costa Del Sol (Spain). Sustainability, 11, 1-14. https://doi.org/10.3390/su11020409

[46] Kline, C., Lee, S.J. and Knollenberg, W. (2018) Segmenting Foodies for a Foodie Destination. Journal of Travel \& Tourism Marketing, 35, 1234-1245. https://doi.org/10.1080/10548408.2018.1488647

[47] Sidali, L.K. and Hemmerling, S. (2014) Developing an Authenticity Model of Traditional Food Specialties: Does the Self-Concept of Consumers Matter? British Food Journal, 116, 1692-1709. https://doi.org/10.1108/BFJ-02-2014-0056

[48] Lopez-Guzmán, T., Uribe Lotero, C.P., Pérez Gálvez, J.C. and Ríos-Rivera, I. (2017) Gastronomicfestivals: Attitude, Motivation and Satisfaction of the Tourist. British Food Journal, 119, 267-283. https://doi.org/10.1108/BFJ-06-2016-0246

[49] Newman, G.E. and Dhar, R. (2014) Authenticity Is Contagious: Brand Essence and the Original Source of Production. Journal of Marketing Research, 51, 371-386. https://doi.org/10.1509/jmr.11.0022

[50] Harrington, R.J., Ottenbacher, M. and Löwenhagen, N.I.N.A. (2015) Are Culinary and Hospitality Service Attributes Key Predictors of Returning Visits for Culinary Tourism Locations? Journal of Gastronomy and Tourism, 1, 45-55. https://doi.org/10.3727/216929715X14298190828877

[51] Richards, G. (2012) Food and the Tourism Experience: Major Findings and Policy Orientations. In: Dodd, D., Eds., Food and the Tourism Experience, OECD, Paris, 13-46.

[52] McKercher, B., Okumus, F. and Okumus, B. (2007) Food Tourism as a Viable Market Segment: It's All How You Cook the Numbers. Journal of Travel \& Tourism Marketing, 25, 137-148. https://doi.org/10.1080/10548400802402404

[53] Kim, S., Choe, J.Y. and Lee, A. (2016) Efforts to Globalize a National Food: Market Segmentation by Reasons for Ethnic Food Preferences. International Journal of Contemporary Hospitality Management, 28, 2310-2330. https://doi.org/10.1108/IJCHM-03-2015-0151

[54] Getz, D., Robinson, R.N., Andersson, T.D. and Vujicic, S. (2014) Foodies and Food Tourism. Food fellow Publishers, Oxford.

[55] Hwang, J., Kim, S., Choe, J.Y. and Chung, C.-H. (2018) Exploration of the Successful Globalization of Ethnic Food: A Case of Korean Food. International Journal of Contemporary Hospitality Management, 30, 3656-3676. https://doi.org/10.1108/IJCHM-07-2017-0452

[56] Mak, A.H., Lumbers, M. and Eves, A. (2012) Globalisation and Food Consumption in Tourism. Annals of Tourism Research, 39, 171-196. https://doi.org/10.1016/j.annals.2011.05.010

[57] Björk, P. and Kauppinen-Räisänen, H. (2014) Culinary-Gastronomic Tourism: A Search for Local Food Experiences. Nutrition and Food Science, 4, 294-309. https://doi.org/10.1108/NFS-12-2013-0142

[58] Robinson, R.N.S. and Getz, D. (2014) Profiling Potential Food Tourists: An Australian Study. British Food Journal, 116, 690-706. https://doi.org/10.1108/BFJ-02-2012-0030

[59] Chen, Y.-Y. (2013) The Role of Food in Tourists' Experiences: A Case Study of Taiwan. A Doctoral Thesis of Philosophy in Recreation and Leisure Studies, University of Waterloo, Waterloo. https://uwspace.uwaterloo.ca/bitstream/handle/10012/7743/Chen_Ying-Yu.pdf?seq 
$\underline{\text { uence }=1 \text { \&isAllowed }=\mathrm{y}}$

[60] Xuhui, W., Muhammad, A. and Ayyub, S. (2018) Determinants of Consumption Intention of Chinese Cuisines for Foreigners: The Mediating Role of Variety Seeking Behavior. International Journal of Culture, Tourism and Hospitality Research, 12, 213-222. https://doi.org/10.1108/IJCTHR-05-2017-0061

[61] Rahman, M.S., Zaman, M.H., Hassan, H. and Wei, C.C. (2018) Tourist's Preferences in Selection of Local Food: Perception and Behavior Embedded Model. Tourism Review, 73, 111-132. https://doi.org/10.1108/TR-04-2017-0079

[62] Silkes, C.A., Cai, L. and Lehto, X.L. (2013) Marketing to the Culinary Tourist. Journal of Travel \& Tourism Marketing, 30, 335-349.

https://doi.org/10.1080/10548408.2013.784151

[63] Bertella, G. (2011) Knowledge in Food Tourism: The Case of Lofoten and Maremma Toscana. Current Issues in Tourism, 14, 355-371. https://doi.org/10.1080/13683500.2010.489638

[64] Carmen, A.M., Carmen, C.I. and Marta, L.G. (2017) When Do Tourists Really Enjoy Authentic and Exotic Food Experiences? Product Adaption and Tourists' Attitudes. XXIX Congreso De Marketing Aemark, 1038 de 1617.

[65] Carvalho, M., Kastenholz, E. and Carneiro, M.J. (2017) Co-Creating Food Tourism Experiences. Revista Turismo and Desenvolvimento, 2, 49-51.

[66] Ng, S.I., Lee, J.A. and Soutar, G.N. (2007) Tourists' Intention to Visit a Country: The Impact of Cultural Distance. Tourism Management, 28, 1497-1506. https://doi.org/10.1016/j.tourman.2006.11.005

[67] Pérez-Gálvez, J.C., Granda, M.J., Lopez-Guzmán, T. and Coronel, J.R. (2017) Local Gastronomy, Culture and Tourism Sustainable Cities: The Behavior of the American Tourist. Sustainable Cities and Society, 32, 604-612. https://doi.org/10.1016/j.scs.2017.04.021

[68] Okech, R.N. (2014) Developing Culinary Tourism: The Role of Food as a Cultural Heritage in Kenya. Proceedings of the Second International Conference on Global Business, Economics, Finance and Social Science, Chennai, 11-13 July 2014, Paper ID CF412, 1-16.

[69] Hendijani, R.B. (2016) Effect of Food Experience on Tourist Satisfaction: The Case of Indonesia. International Journal of Culture, Tourism and Hospitality Research, 10, 272-282. https://doi.org/10.1108/IJCTHR-04-2015-0030

[70] López-Guzmán, T. and Sánchez-Cañizares, S. (2012) Culinary Tourism in Córdoba (Spain). British Food Journal, 114, 168-179. https://doi.org/10.1108/00070701211202368

[71] Bottyan, I. (2015) The Impact of Domestic Gastronomic Festivals on the Local Accommodations. The Central European Journal of Regional Development and Tourism, 7, 188-205.

[72] Richards, G. and Palmer, R. (2010) Eventful Cities. Rutledge, London.

[73] Duarte, A., O’neill, M., Liu, Y. and O’shea, M. (2013) Factors Driving Consumer Restaurant Choice: An Exploratory Study from the Southeastern United States. Journal of Hospitality Marketing and Management, 22, 547-567. https://doi.org/10.1080/19368623.2012.671562

[74] Srivastava, R.K. (2015) How Differing Demographic Factors Impact Consumers' Loyalty towards National or International Fast Food Chains: A Comparative Study in Emerging Markets. British Food Journal, 117, 1354-1376. https://doi.org/10.1108/BFJ-07-2014-0230 
[75] Cho, M., Bonn, M.A. and Brymer, R.A. (2017) A Constraint-Based Approach to Wine Tourism Market Segmentation. Journal of Hospitality and Tourism Research, 41, 415-444. https://doi.org/10.1177/1096348014538049

[76] Kivela, J. and Crotts, J.C. (2005) Gastronomy Tourism. Journal of Culinary Science and Tourism, 4, 39-55. https://doi.org/10.1300/J385v04n02_03

[77] Wadolowska, L., Babicz-Zelinska, E. and Czarnocinska, J. (2008) Food Choice Models and Their Relation with Food Preferences and Eating Frequency in the Polish Population. Food Policy, 33, 122-134. https://doi.org/10.1016/j.foodpol.2007.08.001

[78] Tsai, C.T. (2016) Memorable Tourist Experiences and Place Attachment When Consuming Local Food. International Journal of Tourism Research, 18, 536-548. https://doi.org/10.1002/jtr.2070

[79] Kalalo, R.S.B., Cablao, A.L.A., Cabatay, M.P., Mantal, C.P., Manalo, R.T. and Felicen, S.S. (2014) Cuisine Preference of Local Tourists in San Juan, Batangas, Philippines. Asia Pacific Journal of Multidisciplinary Research, 2, 101-111.

[80] Rozin, P. (2006) The Integration of Biological, Social, Cultural and Psychological Influences on Food Choice. In: Shepherd, R. and Raats, M., Eds., The Psychology of Food Choice, CAB, Oxfordshire, 19-39. https://doi.org/10.1079/9780851990323.0019

[81] Kim, W., Ng, Y. and Kim, Y. (2009) Influence of Institutional DINSERV on Customer Satisfaction, Return Intention, and Word-of-Mouth. International Journal of Hospitality Management, 28, 10-17. https://doi.org/10.1016/j.ijhm.2008.03.005

[82] Kim, Y.G., Eves, A. and Scarles, C. (2009) Building a Model of Local Food Consumption on Trips and Holidays: A Grounded Theory Approach. International Journal of Hospitality Management, 28, 423-431.

https://doi.org/10.1016/j.ijhm.2008.11.005

[83] Cetin, G. and Bilgihan, A. (2016) Components of Cultural Tourists' Experiences in Destinations. Current Issues in Tourism, 19, 137-154. https://doi.org/10.1080/13683500.2014.994595

[84] Mak, A.H., Lumbers, M., Eves, A. and Chang, R. (2012) Factors Influencing Tourist Food Consumption. International Journal of Hospitality Management, 31, 928-936. https://doi.org/10.1016/j.ijhm.2011.10.012

[85] Bjork, P. and Kauppinen-Raisanen, H. (2016) Local Food: A Source for Destination Attraction. International Journal of Contemporary Hospitality Management, 28, 177-194. https://doi.org/10.1108/IJCHM-05-2014-0214

[86] Okumus, F., Kock, G., Scantlebury, M.M. and Okumus, B. (2013) Using Local Cuisines When Promoting Small Caribbean Island Destinations. Journal of Travel \& Tourism Marketing, 30, 410-429. https://doi.org/10.1080/10548408.2013.784161

[87] Lin, Y.-C., Pearson, T.E. and Cai, L.A. (2011) Food as a Form of Destination Identity: A Tourism Destination Brand Perspective. Tourism and Hospitality Research, 11, 30-48. https://doi.org/10.1057/thr.2010.22

[88] Quan, S. and Wang, N. (2004) Towards a Structural Model of the Tourist Experience: An Illustration from Food Experiences in Tourism. Tourism Management, 25, 297-307. https://doi.org/10.1016/S0261-5177(03)00130-4

[89] Hwang, J. and Lin, T.-N. (2010) Effects of Food Neophobia, Familiarity, and Nutrition Information on Consumer Acceptance of Asian Menu Items. Journal of Hospitality Marketing and Management, 19, 171-187. https://doi.org/10.1080/19368620903455286

[90] Dimitrovski, D. and Crespi-Vallbona, M. (2017) Role of Food Neophilia in Food 
Market Tourists' Motivational Construct: The Case of La Boqueria in Barcelona, Spain. Journal of Travel and Tourism Marketing, 34, 475-487. https://doi.org/10.1080/10548408.2016.1193100

[91] Mynttinen, S., Logrén, J., Särkkä-Tirkkonen, M. and Rautiainen, T. (2015) Perceptions of Food and Its Locality among Russian Tourists in the South Savo Region of Finland. Tourism Management, 48, 455-466.

https://doi.org/10.1016/j.tourman.2014.12.010

[92] Folgado-Fernández, J.A., Hernández-Mogollon, J.M. and Duarte, P. (2017) Destination Image and Loyalty Development: The Impact of Tourists' Food Experiences at Gastronomic Events. Scandinavian Journal of Hospitality and Tourism, 17, 92-110. https://doi.org/10.1080/15022250.2016.1221181

[93] Alderighi, M., Bianchi, C. and Lorenzini, E. (2016) The Impact of Local Food Specialties on the Decision to (re) Visit a Tourist Destination: Market-Expanding or Business-Stealing? Tourism Management, 57, 323-333. https://doi.org/10.1016/j.tourman.2016.06.016

[94] Suhartanto, D. and Triyuni, N.N. (2016) Tourist Loyalty toward Shopping Destination: The Role of Shopping Satisfaction and Destination Image. European Journal of Tourism Research, 13, 84-102.

[95] Yoo, K.H. and Gretzel, U. (2011) Influence of Personality on Travel-Related Consumer-Generated Media Creation. Computers in Human Behavior, 27, 609-621. https://doi.org/10.1016/j.chb.2010.05.002

[96] Prayag, G., Hosany, S., Muskat, B. and Del Chiappa, G. (2017) Understanding the Relationships between Tourists' Emotional Experiences, Perceived Overall Image, Satisfaction, and Intention to Recommend. Journal of Travel Research, 56, 41-54. https://doi.org/10.1177/0047287515620567

[97] Hosany, S. and Witham, M. (2010) Dimensions of Cruisers' Experiences, Satisfaction, and Intention to Recommend. Journal of Travel Research, 49, 351-364. https://doi.org/10.1177/0047287509346859

[98] Ali, F., Ryu, K. and Hussain, K. (2016) Influence of Experiences on Memories, Satisfaction and Behavioral Intentions: A Study of Creative Tourism. Journal of Travel and Tourism Marketing, 33, 85-100. https://doi.org/10.1080/10548408.2015.1038418

[99] Lai, M.Y., Khoo-Lattimore, C. and Wang, Y. (2017) Food and Cuisine Image in Destination Branding: Toward a Conceptual Model. Tourism and Hospitality Research, 19, 238-251. https://doi.org/10.1177/1467358417740763

[100] UNWTO (2017) Second Global Report on Gastronomy Tourism. Affiliate Members Reports, 16. http://cf.cdn.unwto.org/sites/all/files/pdf/gastronomy_report_web.pdf

[101] Marine-Roig, E. and Anton-Clave, S. (2016) Perceived Image Specialization in Multiscalar Tourism Destinations. Journal of Destination Marketing and Management, 5, 202-213. https://doi.org/10.1016/j.jdmm.2015.12.007

[102] Yang, W. and Mattila, A. (2017) The Impact of Status Seeking on Consumers' Word of Mouth and Product Preference: A Comparison between Luxury Hospitality Services and Luxury Goods. Journal of Hospitality and Tourism Research, 41, 3-22. https://doi.org/10.1177/1096348013515920

[103] Daries, N., Cristobal-Fransi, E., Ferrer-Rosell, B. and Marine-Roig, E. (2018) Behaviour of Culinary Tourists: A Segmentation Study of Diners at Top-Level Restaurants. Intangible Capital, 14, 332-355. https://doi.org/10.3926/ic.1090 